\title{
Pengaruh Ekstrak Alga Cokelat (Sargassum sp.) terhadap Pertumbuhan Bakteri Escherichia coli Secara In Vitro

\author{
Effect of Brown Algae Extract (Sargassum sp.) on Growth \\ of Escherichia coli In Vitro
}

Moch. Amin Alamsjah, Dwi Nurhayati dan Wahju Tjahjaningsih

Fakultas Perikanan dan Kelautan Universitas Airlangga

Kampus C Mulyorejo - Surabaya, 60115 Telp. 031 - 5911451

\begin{abstract}
Algae Sargassum sp. showed the ability to inhibit the growth of a maximum of several types of pathogenic bacteria such as Escherichia coli. Because of Sargassum sp. have antibacterial with 2 active ingredients are compounds of phenol and tannin fiber. So Sargassum sp. potential to serve as antibakteri substances against several types of bacterial pathogens such as bacteria that cause diarhea.The aim of the study was to determine antibacterial activity brown algae exstract (Sargassum sp.) and determine best concentration from brown algae exstract (Sargassum sp.) to kill of E. coli.

This study was conducted at several places such as Saints and Technology Faculty and Veterinary Faculty, Airlangga University Surabaya. Research was done September 2010. This study was conducted in the laboratory using experimental method completely randomized design with twelve treatments and there replications. The main objectives of this study were MBC extract of Sargassum sp. Result of the study analyzed with Khi-Khuadrat. Result of the study showed that extract Sargassum sp. has antimicrobial activity against $E$. coli were determined with in vitro method. Based on MBC data were found to be effective to kill of $E$. coli at $50 \%$.

Exploration potential of extracts from brown algae (Sargassum sp.) against various species of bacteria that cause diarrhea are expected to become a new information about the content of extracts of Sargassum sp. as an antibacterial. Also from this research will be obtained an alternative treatment of diarrheal diseases that come from living marine resources and will eventually increase the economic value of fishery commodities which have not explored its use as Sargassum sp.
\end{abstract}

Keywords : brown algae (Sargassum sp.), exstract, E. coli, In vitro

\section{Pendahuluan}

Salah satu kekayaan hayati laut Indonesia adalah rumput laut. Namun, penggunaannya selama itu masih terbatas untuk makanan dan obat. Belum ada upaya pengembangan lebih lanjut pada produk lain yang punya nilai ekonomis lebih tinggi (Irwan, 2003). Menurut Sastry dan Rao (1994), bahwa ekstrak Sargassum menunjukkan kemampuan menghambat pertumbuhan yang maksimal terhadap beberapa jenis bakteri patogen seperti Pseudomonas aeruginosa, Sthapylococcus aureus, Salmonella typhii, dan Escherichia coli, Bacillus cereus dimana hal tersebut dapat diketahui setelah dilakukan suatu percobaan secara in vitro. Dari keterangan tersebut, maka dapat dikatakan bahwa Sargassum sp. potensi untuk dijadikan sebagai bahan antimikroba terhadap beberapa jenis bakteri patogen seperti bakteri penyebab diare. Diare adalah sebuah penyakit di mana penderita mengalami buang air besar yang sering dan masih memiliki kandungan air berlebihan.

Melalui penelitian ini dilakukan suatu eksplorasi potensi ekstrak dari alga cokelat (Sargassum sp.) terhadap berbagai spesies bakteri penyebab diare, sehingga melalui penelitian ini akan diperoleh suatu informasi baru tentang kandungan ekstrak terhadap berbagai spesies bakteri penyebab diare. Selain itu dari penelitian ini akan diperoleh suatu pengobatan alternatif dari penyakit diare yang berasal dari sumber daya hayati laut dan akhirnya akan meningkatkan nilai ekonomis dari komoditas perikanan yang selama ini tidak tereksplorasi kegunaannya seperti Sargassum sp.

\section{Tujuan}

Mengetahui kemampuan daya antibakterial dari ekstrak alga cokelat (Sargassum sp.).

Mengetahui konsentrasi terbaik ekstrak alga coklat (Sargassum sp.) dalam membunuh bakteri $E$. coli.

\section{Manfaat}

Sebagai informasi bagi masyarakat tentang ekstrak Sargassum sp. menggunakan metanol sebagai obat herbal antibakteri untuk berbagai spesies bakteri penyebab diare. Melalui penelitian ini akan diperoleh suatu informasi untuk pengobatan alternatif dari penyakit diare yang berasal dari sumber daya hayati laut. 


\section{Metodologi Penelitian}

Tempat dan Waktu

Penelitian dilaksanakan pada pada bulan September 2010 di Laboratorium Kimia Organik dan Biokima, Fakultas Sains dan Teknologi, Universitas Airlangga dan Laboratorium Bakteriologi dan Mikologi, Fakultas Kedokteran Hewan, Universitas Airlangga.

Materi Penelitian

Bahan Penelitian

Bahan penelitian yang digunakan adalah Sargassum sp. yang diperoleh dari pesisir pantai Madura, bakteri Escherichia coli ATCC 25922 yang diperoleh dari Laboratorium Bakteriologi dan Mikologi, Fakultas Kedokteran Hewan, Universitas Airlangga, metanol, akuades steril, Nutrient Brooth (NB), kertas saring, Eosin Methylen Blue Agar (EMBA), Sulfide Indol Motility (SIM), Triple Sugar Iron Agar (TSIA), Simon Sitrat Agar, Urea Agar. Media untuk uji gula-gula yaitu glukosa, laktosa, maltosa dan sukrosa.

\section{Alat Penelitian}

Peralatan penelitian yang digunakan meliputi rotary vacuum evaporator, tabung erlenmeyer, tabung reaksi, cawan petri, rak, pipet, jarum ose, inkubator, autoclave, mikropipet, pembakar bunsen, mikroskop, kapas, vortex dan object glass.

\section{Metode Penelitian}

Penelitian ini dilaksanakan secara in vitro dengan penentuan Minimum Bactericidal Concentration (MBC) melalui metode dilusi. Menurut Lennete et al. (1974) untuk mengetahui Minimum Bactericidal Concentration (MBC) dilakukan dengan menginokulasikan larutan dari kedua tabung Minimum Inhibitory Concentration (MIC) terjernih pada media Eosin Methylen Blue Agar (EMBA), kemudian diinkubasi $37{ }^{\circ} \mathrm{C}$ selama 24 jam.

Rancangan Pecobaan

Rancangan percobaan menggunakan Rancangan Acak Lengkap (RAL) yang terdiri dari 12 perlakuan dengan 3 kali ulangan. Penelitian ini menggunakan metode pengenceran (dilution methods) melalui Minimum Bactericidal Concentration (MBC) Test.
Prosedur Kerja

Tahapan Persiapan

Pembuatan Simplisia

Simplisia adalah bahan alamiah yang digunakan sebagai obat yang belum mengalami pengolahan apapun kecuali dinyatakan lain berupa bahan yang dikeringkan (Fanani, 2009). Sargassum sp. diperoleh dari pantai pesisir Madura, kemudian dikering anginkan di tempat teduh dengan suhu kamar $25{ }^{\circ} \mathrm{C}$ dan tidak dikeringkan dengan suhu $>$ $45^{\circ} \mathrm{C}$ atau tidak terkena matahari secara langsung (Harbone, 1987).

\section{Ekstrak Sargassum sp.}

Ekstraksi adalah penarikan kandungan kimia yang dapat larut sehingga terpisah dari bahan yang tidak dapat larut dengan pelarut cair. Metode yang digunakan adalah metode maserasi. Maserasi adalah cara ekstraksi yang paling sederhana. Rumput laut sebanyak $3 \mathrm{~kg}$ yang sudah dikeringkan kemudian dimaserasi dengan menggunakan 1 liter methanol . Rumput laut kemudian disaring dengan menggunakan kertas saring dan filtrat ditampung dalam tabung erlenmeyer. Selanjutnya, pelarut diuapkan dengan menggunakan rotary vacuum evaporator pada suhu $40^{\circ} \mathrm{C}$. Ekstrak Sargassum sp. yang didapatkan berupa ekstrak kental (Depkes RI, 2000).

Pembuatan suspensi bakteri Escherichia coli

Pembuatan suspensi kuman E. coli dilakukan dengan cara mengambil koloni pada media EMBA sebanyak 4 - 5 koloni dengan menggunakan jarum ose dan dimasukkan ke dalam NB lalu diinkubasi pada suhu $37^{\circ} \mathrm{C}$ selama 24 jam. Kekeruhan dari suspensi bakteri tersebut disesuaikan dengan kepadatan bakteri $3 \times 10^{8} \mathrm{CFU} / \mathrm{ml}$ (suspensi Mc.Farland). Semua proses dilakukan secara aseptis (Bailey and Scott , 1986).

Pelaksanaan Penelitian

Pembuatan Ekstrak Sargassum sp. dengan Berbagai Konsentrasi

Metode yang digunakan pada penelitian ini metode pengenceran dengan berbagai kosentrasi larutan ekstrak Sargassum sp. Ekstrak Sargassum sp. diencerkan dengan akuades steril. Dalam pembuatan MIC, caranya terlebih dahulu menyiapkan 12 tabung reaksi dan pemberian nomor satu sampai 12. Pada tabung nomor satu dan dua diisi $1 \mathrm{ml}$ ekstrak 
Sargassum sp., kemudian pada tabung nomor dua hingga 10 diisi $1 \mathrm{ml}$ akuades steril. Pada tabung nomor dua diaduk hingga homogen, setelah itu diambil $1 \mathrm{ml}$ dan dimasukkan pada tabung ketiga kemudian diaduk hingga homogen. Demikian seterusnya hingga tabung nomor 10. Dari tabung nomor 10 diambil $1 \mathrm{ml}$ dan dibuang. Adapun perlakuan tersebut adalah sebagai berikut :

Tabung 1 : $1 \mathrm{ml}$ ekstrak Sargassum sp. konsentrasi $100 \%+1 \mathrm{ml}$ suspensi E. coli

Tabung $2: 1 \mathrm{ml}$ ekstrak Sargassum sp. konsentrasi $50 \%+1 \mathrm{ml}$ suspensi E. coli

Tabung $3: 1 \mathrm{ml}$ ekstrak Sargassum sp. konsentrasi 25 $\%+1 \mathrm{ml}$ suspensi $E$. coli

Tabung 4 : $1 \mathrm{ml}$ ekstrak Sargassum $\mathrm{sp}$. konsentrasi 12, $5 \%+1 \mathrm{ml}$ suspensi $E$. coli

Tabung 5 : $1 \mathrm{ml}$ ekstrak Sargassum sp. konsentrasi 6, $25 \%+1 \mathrm{ml}$ suspensi $E$. coli

Tabung 6: $1 \mathrm{ml}$ ekstrak Sargassum sp. konsentrasi $3,125 \%+1 \mathrm{ml}$ suspensi $E$. coli

Tabung $7: 1 \mathrm{ml}$ ekstrak Sargassum sp.konsentrasi $1,5625 \%+1 \mathrm{ml}$ suspensi $E$. coli

Tabung 8:1 ml ekstrak Sargassum sp. konsentrasi $0,781 \%+1 \mathrm{ml}$ suspensi $E$. coli

Tabung $9: 1 \mathrm{ml}$ ekstrak Sargassum sp. konsentrasi $0,391 \%+1 \mathrm{ml}$ suspensi E. coli

Tabung $10: 1 \mathrm{ml}$ ekstrak Sargassum sp. konsentrasi $0,195 \%+1 \mathrm{ml}$ suspensi E. Coli dan diambil $1 \mathrm{ml}$ kemudian dibuang, sehingga volumenya tinggal $1 \mathrm{ml}$ Tabung $11: 1 \mathrm{ml}$ ekstrak Sargassum sp. $+1 \mathrm{ml}$ akuades steril sebagai kontrol positif $(+)$

Tabung 12: $1 \mathrm{ml}$ suspensi E. coli $+1 \mathrm{ml}$ akuades steril sebagai kontrol negatif(-)

Setelah itu diinkubasi pada suhu pada suhu $37{ }^{\circ} \mathrm{C}$ selama 24 jam

Penentuan Minimal Bactericidal Concentration (MBC)

Terlebih dahulu disiapkan media EMBA steril. Selanjutnya kedua tabung MIC terjernih diambil 0,025 ml dengan menggunakan mikropipet kemudian ditanam pada media EMBA sesuai dengan nomor. Kemudian diinkubasi pada suhu $37^{\circ} \mathrm{C}$ selama 24 jam. Selanjutnya hasil inkubasi diamati untuk menentukan ada tidaknya pertumbuhan bakteri E. coli. Hasil yang diamati adalah konsentrasi terendah yang tidak terdapat pertumbuhan bakteri (Bailey and Scott, 1986).

\section{Analisis Data}

Data hasil penelitian diolah secara statistik menggunakan Khi-Khuadrat dengan tingkat signifikan 0,05\% (Schefler, 1987). Dari 12 perlakuan hanya akan dilakukan pengamatan pada dua tabung terjernih, kemudian akan digolongkan ke dalam data enumerasi yaitu tidak tumbuh dan tumbuh.

\section{Hasil dan Pembahasan}

Identifikasi Bakteri Escherichia coli

Identifikasi bakteri dilakukan untuk memastikan kebenaran identitas bakteri E. coli yang diperoleh dari Laboratorium Bakteriologi dan Mikologi, Fakultas Kedokteran Hewan, Universitas Airlangga, Surabaya. Metode yang digunakan adalah pengamatan morfologi koloni bakteri dan pengamatan secara mikroskopik menggunakan pewarnaan Gram serta pengujian sifat biokimia dari E. coli (Cowan dan Steel's, 1981). Berdasarkan pengamatan morfologi koloni bakteri, pewarnaan Gram dan pengujian sifat biokimia dari kultur murni bakteri E. coli, diperoleh hasil identifikasi bakteri seperti ditampilkan pada Tabel 1.

Tabel 1. Hasil uji biokimia bakteri Eschericia coli

\begin{tabular}{lc}
\hline \multicolumn{1}{c}{ Parameter } & Hasil \\
\hline Warna koloni (EMBA) & Hijau metalik \\
Bentuk koloni & Bundar \\
Pewarnaan gram : & Negatif \\
Bentuk sel & Batang \\
Motilitas & + \\
Produksi H2S & - \\
Produksi Indol & + \\
Uji gula-gula : & \\
Glukosa & + \\
Laktosa & + \\
Maltosa & + \\
Sukrosa & + \\
\hline
\end{tabular}

Berdasarkan pengamatan ciri-ciri tersebut, setelah dibandingkan dengan ciri-ciri bakteri yang diuraikan oleh Puspaningrum (2008), Acun (2010) dan Ardian (2010) maka bakteri ini diidentifikasikan sebagai bakteri E. coli.

Hasil penelitian mengenai daya antibakteri ekstrak Sargassum sp. terhadap bakteri E. coli dilakukan dengan metode dilusi yaitu penentuan hasil Minimum Bactericidal Concentration (MBC) yaitu konsentrasi minimum yang dapat membunuh bakteri E. coli (Bailey and Scott's, 1994). Hasil pengamatan uji MBC menunjukkan bahwa pada konsentrasi pengenceran $100 \%$ dan $50 \%$ ekstrak Sargassum sp. tidak memberikan perbedaan nyata terhadap pertumbuhan bakteri $E$. coli secara in vitro.

Hasil penelitian tentang daya antibakteri ekstrak Sargassum sp. dapat diketahui bahwa ekstrak Sargassum sp. mempunyai aktivitas menghambat 
pertumbuhan bakteri E. coli. Hasil pengamatan uji MIC secara visual menunjukkan hambatan pertumbuhan terjadi pada konsentrasi $50 \%$. Hal ini tampak pada tabung reaksi konsentrasi $50 \%$ yang memiliki kejernihan hampir mendekati kejernihan tabung reaksi kontrol positif dan tidak keruh seperti tabung reaksi tabung kontrol negatif.

Penelitian ini dilaksanakan di dalam laboratorium dengan kondisi aseptis dan dalam keadaan terkontrol. Hal ini dibuktikan bahwa tidak terdapat pertumbuhan koloni bakteri lain selain bakteri E. coli pada media EMBA. Hal ini sesuai dengan pendapat Christofilogiannis (2001) yang menyatakan bahwa, faktor-faktor yang dapat mempengaruhi keakuratan hasil akhir uji MIC antara lain : agen antibakteri, suhu, jumlah inokulum bakteri yang digunakan dalam media kultur. $\quad \mathrm{MBC}$ ekstrak Sargassum sp. pada konsentrasi $50 \%$ terdapat pertumbuhan koloni bakteri $E$. coli hanya pada ulangan 1, sedangkan ulangan ke 2 dan ulangan ke 3 tidak terdapat pertumbuhan bakteri. Hal ini dikarenakan ekstrak Sargassum sp. mempunyai daya antibakterial terhadap E. coli. Trono dan Ganzon (1988) menyatakan bahwa kandungan bahan kimia utama dari Sargassum sp. adalah sumber alginat, tanin dan fenol. Ekstrak Sargassum sp. mempunyai kandungan antibakteri berupa senyawa fenol dan serat tanin berperan utama sebagai penghambat pertumbuhan koloni bakteri patogen (Kandhasamy dan Arunachalam, 2008). Mekanisme kerja senyawa fenol dalam membunuh sel bakteri, yaitu dengan cara mendenaturasi protein sel bakteri (Purwanti, 2007). MBC ekstrak Sargassum sp. dapat ditentukan setelah menginokulasikan larutan ekstrak Sargassum sp. dari dua tabung MIC terjernih yaitu konsentrasi $100 \%$ dan $50 \%$ pada media EMBA.

Tabel 2. Hasil pengamatan uji Minimum Bactericidal Concentration (MBC)

\begin{tabular}{|c|c|c|c|c|}
\hline \multirow{2}{*}{$\begin{array}{l}\text { Nomor } \\
\text { Cawan }\end{array}$} & \multirow{2}{*}{$\begin{array}{c}\text { Konsentrasi } \\
(\%)\end{array}$} & \multicolumn{3}{|c|}{ Ulangan } \\
\hline & & $\mathrm{I}$ & II & III \\
\hline \multicolumn{2}{|c|}{ Kontrol Positif } & - & - & - \\
\hline 1 & 100 & - & - & - \\
\hline 2 & 50 & + & - & - \\
\hline \multicolumn{2}{|c|}{ Kontrol Negatif } & + & + & + \\
\hline
\end{tabular}

Keterangan : (-) : Tidak tumbuh koloni $(+)$ : Tumbuh koloni

Pada Tabel 2 dapat dilihat ekstrak Sargassum sp. pada konsentrasi $50 \%$ terdapat pertumbuhan koloni bakteri E. coli pada ulangan 1, sedangkan pada ulangan 1 dan 2 tidak terdapat pertumbuhan koloni bakteri E. coli. Pada konsentrasi $100 \%$ tidak terdapat pertumbuhan koloni bakteri E. coli sama sekali pada ulangan 1 sampai dengan ulangan 3. Berdasarkan hasil uji MBC ekstrak Sargassum sp. mempunyai aktifitas menghambat atau bersifat bakteriostatik terhadap bakteri E. coli pada konsentrasi $50 \%$.

Konsentrasi $50 \%$ mempunyai kemampuan menghambat bakteri E. coli sehingga dapat diduga bahwa ekstrak Sargassum sp. lebih efektif bila digunakan sebagai obat. Hasil dugaan ini didukung oleh Gonzales et al., (2001) yang menyatakan bahwa alga cokelat mempunyai kemampuan antibakterial pada konsentrasi 53 \%. Ernst (1991) menyatakan, untuk terapi obat yang bermanfaat, pemberian konsentrasi yang cukup dan tidak berlebihan merupakan syarat utama. Pemberian konsentrasi yang cukup, berarti pemberian konsentrasi yang dapat menimbulkan efek yang diinginkan tanpa konsentrasi yang berlebihan, sehingga efek toksik dapat dihindari.

Senyawa aktif lain yang dapat membunuh bakteri E. coli adalah tanin. Diduga tanin dapat digunakan sebagai antibakteri. Hal ini sesuai dengan pendapat Juliantina (2007) yang menyatakan bahwa tanin memiliki aktivitas antibakteri, secara garis besar mekanisme yang diperkirakan adalah toksisitas tanin dapat merusak membran sel bakteri dan senyawa astringent. Tanin diduga dapat mengkerutkan dinding sel atau membran sel sehingga mengganggu permeabilitas sel itu sendiri. Akibat terganggunya permeabilitas, sel tidak dapat melakukan aktivitas hidup sehingga pertumbuhannya terhambat atau bahkan mati.

\section{Kesimpulan}

Ekstrak Sargassum sp. dapat membunuh bakteri E. coli secara in vitro.

Konsentrasi minimum ekstrak Sargassum sp. yang dapat menghambat E. coli adalah 50\%.

Perlu dilakukannya penelitian lebih lanjut secara in vivo terhadap hewan coba sehingga dapat dijadikan informasi dasar dalam penerapan obat alternatif di lapangaan sebagai bentuk pencegahan dalam penanganan penyakit yang disebabkan karena bakteri E. coli.

\section{Daftar Pustaka}

Acun, Sodiyc. 2010. Tabel Uji Biokimia Bakteri Familia Enterobacteriaceae. Jakarta. http://sodiycxacun.com/2010/07/tabel-ujibiokimia-bakteri-familia.html. 
Ardian. 2010. Uji Biokimia Metabolisme Bakteri. Jakarta. http://dydear.multiply.com/journal/ item/3/Uji_Biokimia_Mikroba.

Bailey and Scott's. 1994. Diagnostic Microbiology. $8^{\text {th }}$ Edition. Toronto. p. 313-328.

Bailey. W. R and E. G. Scott. 1986. Diagnostic Microbiology. $7^{\text {th }}$ Ed. The CV. Mosby Company. Saint Louis.

Christofilogiannis, P. 2001. Current Inoculation Methods in MIC Determination. Aquaculture, 208:1-10.

Cowan and Steel's. 1981. Manual for the Identification of Medical Bacteria. Second edition. Cambridge University Press. New York.

Depkes RI. 2000. Parameter Standart Umum Ekstrak Tumbuhan Obat. Direktorat Pengawasan Obat Tradisional. Jakarta.

Ernst, M. 1991. Dinamika Obat.Alih Bahasa : M. B. Widianto.ITB Press. Bandung.

Fanani, Rizal. 2009. Uji Toksisitas Akut Ekstrak Etanol Daun Dewandaru (Eugenia uniflora L. ) Per Oral pada Tikus Galur Spragues Dawley. Fakultas Farmasi. Universitas Muhammadiyah Surakarta. Surakarta.

Gonzales A., B. Angela., M. J. Rio and F. Pelaez. Screening of antimicrobial activities in red, green, and brown macroalgaes from Gran Canaria (Canary Islands, Spain). Spain. 4 : 35-40.

Harbone, J. B. 1987. Metode Fitokimia. Penuntun Cara Menganalisa Tumbuhan. ITB.

Irwan. 2003. Menggali Manfaat Rumput Laut. Riset Unggulan ITB. Bandung.

Juliantina,F. R. 2007. Manfaat Sirih Merah (Piper crocatum) Sebagai Agen Anti Bakterial Gram Negatif dan Gram Positif. Jurnal Kedokteran dan Kesehatan Indonesia. Yogyakarta.
Kandhasamy, M dan K.D. Arunachalam. 2008. Evaluation of in vitro antibacterial property of seaweeds of southeast coast of India African Journal of Biotechnology Vol. 7 (12), pp. http://www.academicjournals.org/AJB. 18/09/2008.

Lennete, H. Edwin, E. H. Spaulding and J. P. Truant. 1974. Manual Clinical Microbiology. Second Edition. American society for Microbiology. Washington D.C.

Purwanti, Elly. 2007. Senyawa Bioaktif Tanaman Sereh (Cymbopogon nardus) Ekstrak Kloroform dan Etanol serta Pengaruhnya Terhadap Mikroorganisme Penyebab Diare. Jurysan Pendidikan Biologi. Fakultas Pendidikan Biologi dan Ilmu Pendidikan. Universitas Muhammadiyah Malang.

Puspaningrum, Anglia. 2008. Penerapan Metode Konvensional pada Escherichia coli. Universitas Indonesia. Jakarta.

Sastry and Rao. 1994. Antibacterial Substance From Marine Algae. Successive Extraction Using Benzene, Chloroform and Methanol. Department of Biochemistry, Institute of Medical Science, Banaras Hindu University. India.

Schelfler, C. William. 1987. Statistika Untuk Biologi, farmasi, Kedokteran, dan Ilmu yang Bertautan. Terbitan kedua. ITB. Bandung.

Trono, J.R. G.C and E.T. Ganzon 1988. Philippine Seaweeds Publ. by National book store. Inc. 
